\title{
Oligomerization of the Bacillus subtilis division protein DivIVA
}

\author{
Katarína Muchová, ${ }^{1}$ Eva Kutejová, ${ }^{1}$ David J. Scott, ${ }^{2,3}$ \\ James A. Brannigan, ${ }^{2}$ Richard J. Lewis, ${ }^{2}+$ Anthony J. Wilkinson ${ }^{2}$ \\ and Imrich Barák ${ }^{1}$
}

Author for correspondence: Imrich Barák. Tel: +42175941 2152. Fax: +42175477 2316.

e-mail: umbibara@savba.sk

\footnotetext{
1 Institute of Molecular Biology, Slovak Academy of Sciences, 84251 Bratislava, Slovakia

2 Structural Biology Laboratory, Department of Chemistry, University of York, Heslington, York YO10 5DD, UK

3 Department of Biology, University of York, Heslington YO10 5YW, UK
}

\begin{abstract}
DivIVA appears to be a mediator of inhibition by MinCD of division at the cell poles in Bacillus subtilis. Gel permeation and ultracentrifugation techniques were used to show self-association of DivIVA into a form consisting of 10-12 monomers in vitro. Western blot analysis of non-denaturating polyacrylamide gels confirms the presence of similar oligomers in B. subtilis cell lysates. These oligomers persist in a B. subtilis strain containing the divIVA1 mutation, in which proper vegetative septum positioning is abolished. In contrast, the divIVA2 mutation, which has a similar biological impact, appears to produce a protein with different oligomerization properties. The results of the present study suggest that oligomerization of DivIVA is important, but not sufficient for its function in the cell division process.
\end{abstract}

Keywords: cell division, blue native electrophoresis, analytical ultracentrifugation, sporulation

\section{INTRODUCTION}

The process of cell division in both Escherichia coli and Bacillus subtilis, in common with most bacteria, is initiated by the formation of an FtsZ ring-like structure at the mid-cell site. Selection of this site for cell division is controlled by the Min system. This system is best characterized in E. coli where it consists of three proteins: MinC, MinD and MinE. MinC and MinD are inhibitors of septation, and MinE imparts topological specificity, ensuring medial cell division (Rothfield \& Zhao, 1996). MinE accumulates at or near the mid-cell site during cell division and the formation of a MinE ring-like structure is dependent on MinD but independent of FtsZ (Raskin \& de Boer, 1997). MinE is likely to exist as a mixture of monomers and dimers in the cytoplasm (Zhang et al., 1998). Visualization of MinD in living cells reveals that this protein oscillates rapidly between the cell poles (Raskin \& de Boer, 1999). A similar oscillation has been observed for MinE (Fu et al., 2001). The topological specificity of division site placement may therefore not involve the localized action of MinE to counteract MinCD mid-cell division in-

\footnotetext{
†Present address: Laboratory of Molecular Biophysics, The Rex Richards Building, University of Oxford, South Parks Road, Oxford OX1 3QU, UK.

Abbreviation: GFP, green fluorescent protein.
}

hibition, but instead reflect the ability of MinE to move the division inhibitor away from the mid-cell to the cell poles (Fu et al., 2001).

Although there are many similarities in cell division between E. coli and B. subtilis, it appears that bacilli employ a different strategy to initiate mid-cell division. B. subtilis has MinCD homologues but lacks a MinE counterpart. MinCD inhibition seems to be mediated through the unrelated protein DivIVA. This protein ensures that MinCD specifically inhibits division at the cell poles whilst allowing division at the mid-cell during vegetative growth (Cha \& Stewart, 1997; Edwards \& Errington, 1997). DivIVA localizes to both cell poles as well as to the mid-cell site (Edwards \& Errington, 1997). Localization of DivIVA to division sites is dependent not only on FtsZ, but also on other cell-division proteins, including DivIB, DivIC and PbpB (Marston et al., 1998). DivIVA is targeted to the division sites late in their assembly, where it recruits MinD to prevent another division from taking place near the newly formed cell poles. MinD is required both to pilot MinC to the cell poles and to constitute a functional division inhibitor. Sequestration of MinD and subsequently MinC to the cell poles makes available the next mid-cell sites in the newly formed cells for division. Recent results show that the main role of DivIVA is to retain MinCD at the cell poles after the division is complete. After division nears completion, all of the components of the division 
apparatus except DivIVA seem to disappear from this site. Therefore, it appears that at some point DivIVA must become attached to a more permanent anchor at the mature cell pole (Marston \& Errington, 1999).

The same pattern of DivIVA targeting seen in B. subtilis was observed when a DivIVA-GFP fusion protein was expressed in E. coli (Edwards et al., 2000). The subcellular targeting of DivIVA in E. coli is dependent on FtsZ and independent of the MinCD system. However, DivIVA does not seem to be able to substitute for MinE, a topological specificity factor in E. coli. Surprisingly, the DivIVA-GFP fusion protein was also directed to nascent division sites in the yeast Schizosaccharomyces pombe (Edwards et al., 2000) and it is thus possible that some conserved target for DivIVA exists in both prokaryotes and eukaryotes.

In contrast to E. coli, B. subtilis can undergo an asymmetric septation during the process of sporulation. It has been shown that at the onset of sporulation, assembly of the FtsZ ring shifts from the mid-cell to both polar sites (Levin \& Losick, 1996), the switch being dependent on the transcription factor Spo0A. The FtsZ ring forms initially at both polar sites, implying that MinCD inhibition of FtsZ assembly at both sites must be overcome early in the sporulation process. MinCDdeficient cells that have begun to sporulate can form sporulation-like septa at both the normal asymmetric position as well as at, or near, the mid-cell site (Barák et al., 1998). However, the role of DivIVA in sporulation septation is unclear, although it was proposed that an unknown sporulation factor interacts with DivIVA to make polar sites available for septation (Cha \& Stewart, 1997).

DivIVA is a $19.5 \mathrm{kDa}$ cytoplasmic protein that has sequence similarity to homologues from other Grampositive bacteria and at a lower level to eukaryotic proteins, including myosin (Edwards et al., 2000). Computer analysis of the DivIVA amino acid sequence suggested that the central region of DivIVA might form an $\alpha$-helical coiled-coil structure in vivo (Edwards et al., 2000). Such structures could be used for oligomerization as in tropomyosin (Lupas, 1996). To examine the possibility that the predicted $\alpha$-helical coiled-coil structure in DivIVA is involved in protein oligomerization, we have cloned the B. subtilis divIVA gene into an E. coli expression system. The encoded protein has been purified to homogeneity and analysed by analytical ultracentrifugation and blue native polyacrylamide gel electrophoresis. We have also characterized the oligomerization state of three different mutant proteins: DivIVA1, DivIVA2 and DivIVA9.

\section{METHODS}

Bacterial strains, plasmids and culture media. All bacterial strains and plasmids used in this study are listed in Table 1. Unless otherwise indicated, E. coli and B. subtilis cultures were grown in Luria-Bertani (LB) medium (Ausubel et al., 1987). The B. subtilis divIVA gene was amplified by PCR using the primers 5'-ATGGAGGTGGCCATATGCCATTAACGCCAAATG-3' and 5'-GGCCATCCCGGATCCTCACCATCTCC-3', introducing NdeI and BamHI sites, respectively (underlined). After excision of the band from an agarose gel, PCR product was purified using the Wizard PCR preps DNA purification system (Promega). The NdeI-BamHI cut PCR fragment was inserted between the same sites in the plasmid pET26b $(+)$ to generate pETIVA. Plasmids from different clones were isolated, analysed by restriction endonucleases and those with correct length inserts were further analysed by DNA sequencing.

pUKIVA plasmid derivatives were constructed by recloning $\operatorname{divIVA}$ mutant genes into the pUK19 backbone by using $B a m \mathrm{HI}$ and $\mathrm{XbaI}$ sites.

Expression, purification and electrophoresis of proteins. Protein overexpression was performed by using E. coli strain IB706. Cell cultures were grown in LB medium containing $30 \mu \mathrm{g}$ kanamycin $\mathrm{ml}^{-1}$ to an $\mathrm{OD}_{600}$ of $0 \cdot 6$, when protein expression was induced by the addition of IPTG to a final concentration of $1 \mathrm{mM}$. After $3 \mathrm{~h}$ further growth, the cells were harvested by centrifugation and frozen at $-80^{\circ} \mathrm{C}$. Then $3.5 \mathrm{~g}$ cells were resuspended on ice in $10 \mathrm{ml}$ buffer A $150 \mathrm{mM}$ Tris/ $\mathrm{HCl} \mathrm{pH} 8 \cdot 0,100 \mathrm{mM} \mathrm{NaCl}, 1 \mathrm{mM}$ EDTA, $1 \mathrm{mM}$ DTT, $1 \mathrm{mM}$ PMSF), lysed by sonication and clarified by centrifugation at $30000 \mathrm{~g}$ for $30 \mathrm{~min}$. The soluble cell lysate was applied to a $13 \mathrm{ml}$ Q Sepharose Fast Flow column (Pharmacia Biotech) pre-equilibrated in buffer A. DivIVA9 was eluted with a linear gradient of $0 \cdot 1-0 \cdot 5 \mathrm{M} \mathrm{NaCl}$. Fractions containing DivIVA9 were diluted fivefold with buffer A and the procedure was repeated using an FPLC Mono Q HR 10/16 column (Pharmacia Biotech). Fractions containing DivIVA9, which eluted at $300 \mathrm{mM} \mathrm{NaCl}$, were concentrated to a volume of $1 \mathrm{ml}$ and loaded onto a Pharmacia Superose 12 gel filtration column.

Western blot analysis of $B$. subtilis cell lysates fractionated by blue native gel electrophoresis was performed as follows. $B$. subtilis cell cultures were grown in DSM medium (Harwood $\&$ Cutting, 1988) at $37^{\circ} \mathrm{C}$ until the onset of stationary phase. The cells were harvested by centrifugation and resuspended in buffer A containing $0 \cdot 25 \mathrm{mg}$ lysozyme $\mathrm{ml}^{-1}$. The cells were lysed by sonication and the suspension clarified by centrifugation at $30000 \mathrm{~g}$ for $15 \mathrm{~min}$. An equal amount $(75 \mu \mathrm{g})$ of protein from each sample was mixed with glycerol $(15 \%, \mathrm{v} / \mathrm{v})$ and electrophoresed through a blue native 5-18\% linear gradient polyacrylamide gel. The proteins were blotted onto a nitrocellulose membrane for immunodetection of DivIVA.

Analytical ultracentrifugation. All analytical ultracentrifugation experiments were performed in a Beckman XL-A analytical ultracentrifuge (Beckman-Coulter) using an AN-Ti 60 rotor. The molecular mass averages were determined using the program BIOSPIN and were as follows:

The number average:

$\left\langle M_{n}\right\rangle=\frac{\sum_{i} c_{i}}{\sum_{i} c_{i} / M_{i}}$

The weight average:

$\left\langle M_{w}\right\rangle=\frac{\sum_{i} M_{i} c_{i}}{\sum_{i} c_{i}}$ 
Table 1. Bacterial strains and plasmids used in this study

\begin{tabular}{|c|c|c|}
\hline Strain or plasmid & $\begin{array}{c}\text { Genotype, phenotype or relevant } \\
\text { characteristics }\end{array}$ & Source or reference \\
\hline \multicolumn{3}{|l|}{ E. coli strains } \\
\hline MM294 & endA1 hsdR17 supE44 thi-1 rec $A^{+}$ & Backman et al. (1976) \\
\hline BL21(DE3) & $F^{-} o m p T h s d S_{\mathrm{B}}\left(\mathrm{r}_{\mathrm{B}}^{-} m_{\mathrm{B}}^{-}\right) g a l d c m$ & Novagen \\
\hline IB706 & pETIVA9 in BL21 & This work \\
\hline IB708 & pETIVA2 in BL21 & This work \\
\hline \multicolumn{3}{|l|}{ B. subtilis strains } \\
\hline PY 79 & Prototroph & Youngman et al. (1984) \\
\hline KSS1168 & $\operatorname{divIVA1} \operatorname{trp} C 2$ & Cha \& Stuart (1997) \\
\hline IB703 & PY79::pUKIVA9 & This work \\
\hline IB704 & PY79::pUKIVA2 & This work \\
\hline \multicolumn{3}{|l|}{ Plasmids } \\
\hline $\mathrm{pET} 26 \mathrm{~b}(+)$ & $\mathrm{Km}^{\mathrm{R}}$, lacI; T7 promoter & Novagen \\
\hline pETIVA9 & $\mathrm{Km}^{\mathrm{R}}$, lacI; T7 promoter, divIVA9 & This work \\
\hline pETIVA2 & $\mathrm{Km}^{\mathrm{R}}$, lacI; T7 promoter, divIVA2 & This work \\
\hline pUK19 & $\mathrm{Amp}^{\mathrm{R}} \mathrm{Km}^{\mathrm{R}}$ & Gift from B. Haldenwang \\
\hline pUKIVA9 & $\mathrm{Amp}^{\mathrm{R}} \mathrm{Km}^{\mathrm{R}}$, divIVA9 & This work \\
\hline pUKIVA2 & $\mathrm{Amp}^{\mathrm{R}} \mathrm{Km}^{\mathrm{R}}$, divIVA2 & This work \\
\hline
\end{tabular}

The $z$-average molecular mass:

$\left\langle M_{z}\right\rangle=\frac{\sum_{i} M_{i}^{2} c_{i}}{\sum_{i} M_{i} c_{i}}$

$M$, molecular mass; $\mathrm{c}$, concentration $\left(\mathrm{mg} \mathrm{ml}^{-1}\right)$.

Light and fluorescence microscopy. Cells were prepared for fluorescence microscopy as described previously (Barák et al., 1996). An Olympus BX60 microscope and MicroImage software was used for microscopy observations, using a filter set for FM 4-64 visualization $(550-583 \mathrm{~nm}$ excitation and $617-690 \mathrm{~nm}$ emission).

\section{RESULTS AND DISCUSSION}

\section{Overexpression of $B$. subtilis DivIVA in E. coli}

To overexpress DivIVA in E. coli, the divIVA gene was placed under the control of the T7 promoter in plasmid pET26b $(+)$ (see Methods). After transformation of E. coli strain MM294, several clones were obtained which were analysed by restriction enzyme cleavage and/or DNA sequencing. Surprisingly, in every case the plasmids had acquired mutations or deletions in the divIVA gene even in the absence of induction of divIVA expression. In addition to a number of deletions, we have isolated two separate point mutations, divIVA9 (Glu162Lys) and divIVA2 (Leu120Pro), along with mutations that introduce stop codons at various positions within the gene. It seems that even low-level expression of divIVA is division-inhibitory to E. coli. Edwards et al. (2000) recently showed that a GFPDivIVA fusion protein is targeted in E. coli to the division sites just as it is in B. subtilis. It is likely that DivIVA interacts with the E. coli division apparatus in a way that inhibits growth, so presumably deletions and mutations that negate such inhibition would be selected. Interestingly, deletion mutations in $\operatorname{divIVA}$ were also acquired when a second copy of $\operatorname{divIVA}$ was placed under the control of the spac promoter in B. subtilis (Cha \& Stewart, 1997), implying that expression of DivIVA at slightly higher than normal levels is also inhibitory in B. subtilis. It is intriguing how such small amounts of protein can influence cell growth. DivIVA probably interacts with one or more components of the division machinery, which is conserved between $B$. subtilis and E. coli. A possible partner for such an interaction is FtsA, which has weak homology to eukaryotic actin (Edwards et al., 2000).

Based on the observation that the last seven amino acid residues of the protein are not necessary for the function of DivIVA (Cha \& Stewart, 1997), we chose DivIVA9 for our next biochemical experiments. The divIVA9 gene contains a single base transition at nucleotide 484, which results in a glutamate to lysine amino acid substitution at residue 162 (the third residue from the $\mathrm{C}$ terminus) in the protein product. Protein was overexpressed in E. coli BL21(DE3) transformed with pETIVA9. SDS-PAGE analysis of cell extracts showed a high level of DivIVA9 production (not shown). Although large amounts of DivIVA9 partitioned into the membrane fraction, sufficient DivIVA9 remained in the soluble fraction to allow protein purification. FPLC purified protein was loaded on a Superose 12 gel filtration column (see Methods). DivIVA9 exhibits a low retention volume, suggesting it exists as a high molecular mass species. To determine the molecular mass of this oligomer, blue native polyacrylamide gradient gel electrophoresis and analytical ultracentrifugation studies were performed. 
(a)

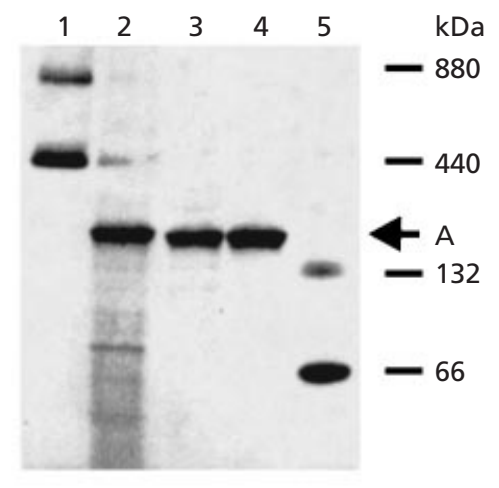

(b)

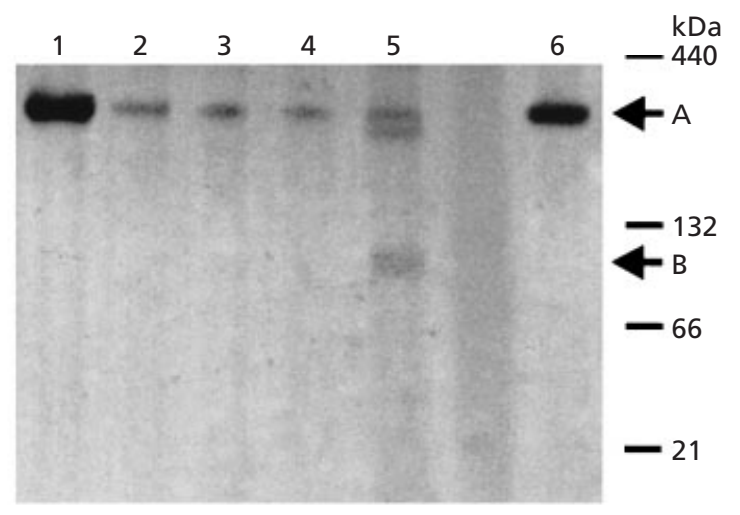

Fig. 1. Electrophoretic analysis of DivIVA proteins. (a) $5-18 \%$ gradient blue native gel electrophoresis. Lanes: 1 , molecular mass marker - ferritin dimer $(880 \mathrm{kDa})$ and ferritin monomer $(440 \mathrm{kDa}) ; 2,100 \mu \mathrm{g}$ cell lysate from induced $E$. coli IB706 strain; 3, DivIVA9 fraction after FPLC Mono Q HR 10/16 column; 4, DivIVA9 fraction after Superose 12 gel filtration column; 5, molecular mass marker - BSA dimer (132.4 kDa) and monomer (66.2 kDa). (b) Western blot analysis of DivIVA proteins fractionated by blue native $8-12 \%$ gradient gel electrophoresis. DivlVA was detected by incubation with the primary antiserum diluted 1:2000, followed by alkaline phosphatase-conjugated anti-mouse IgG diluted 1:1000. Lanes: 1, DivIVA9 protein $(1 \mu \mathrm{g})$ expressed and purified from E. coli; $2-4,75 \mu \mathrm{g}$ cell lysates from B. subtilis strains PY79 (wild-type) (2), KSS1168 (divIVA1) (3), IB703 (divIVA9) (4); 5, $6 \mu$ g cell lysate from the $E$. coli IB708 (divIVA2) expression strain after $3 \mathrm{~h}$ induction with $1 \mathrm{mM}$ IPTG; $6,6 \mu \mathrm{g}$ cell lysate from the $E$. coli IB706 (divIVA9) expression strain after $3 \mathrm{~h}$ induction with $1 \mathrm{mM}$ IPTG. Molecular mass markers were ferritin monomer (440 kDa), BSA dimer (132.4 kDa), BSA monomer $(66.2 \mathrm{kDa})$ and soybean trypsin inhibitor $(21.5 \mathrm{kDa})$. The protein oligomers corresponding to 10-12 mer (A) and $5-6$ mer (B) are marked by arrows.

\section{Blue native gel electrophoresis}

The negative charge of protein-bound Coomassie blue G-250 dye is the main determinant of sample electrophoretic mobility in this method, which is suitable for determining the apparent molecular masses of proteins with a pI below 8.6 (Schägger et al., 1994). The theoretical pI of DivIVA is $4 \cdot 6$, thus DivIVA was resolved by blue native gel electrophoresis with a $5-18 \%$ linear acrylamide gradient. The electrophoretic mobility of protein standards is linearly dependent on $\log M_{r}$, allowing the molecular mass of DivIVA9 to be estimated at $200 \mathrm{kDa}$, corresponding to a decamer (Fig. 1a).

\section{Analytical ultracentrifugation}

Analytical ultracentrifugation is a preferred method of determining absolute molecular mass since, unlike gel filtration, it does not depend on the assumption that the macromolecule under investigation is spherical (Harding, 1994; Laue \& Stafford, 1999). To explore oligomerization of DivIVA9, sedimentation equilibrium studies were carried out at loading concentrations of $0 \cdot 1$, 0.25 and $0.5 \mathrm{mg} \mathrm{ml}^{-1}$. The number average molecular mass $M_{n}$, the weight average molecular mass $M_{\mathrm{w}}$ and the $z$-average molecular mass $M_{\mathrm{z}}$ were determined (Roarke \& Yphantis, 1969). Each of these molecular mass averages is weighted increasingly towards the higher oligomers, so that the number average will reflect the lower order molecular mass oligomers, whereas the $z$-average molecular mass reflects the higher order oligomers. The oligomeric state of DivIVA9 increases from a value expected for a dimer, to one corresponding to a 10-12 mer (Fig. 2a). To assess the stoichiometry of oligomerization further, two species plots of $1 / M_{\mathrm{w}}$ vs $1 / M_{\mathrm{z}}$ were made (Roarke \& Yphantis, 1969). The two plots for the highest loading concentrations of DivIVA9 suggest that the lowest observed molecular mass corresponds to a dimer whereas the highest is consistent with a 10-12 mer (Fig. 2b). Since the molecular mass averages approach an asymptotic value, it can be concluded that higher order aggregates of DivIVA9 do not exist under the experimental conditions. These results, and those from blue native gel electrophoresis, are in good agreement. It appears therefore that DivIVA9 forms several oligomers in vitro, the largest of which is a $10-12$ mer.

\section{DivIVA mutant proteins oligomerize differently}

The purified DivIVA9 protein was also used to raise a murine polyclonal antiserum that had a high specificity as revealed by Western blotting (Fig. 1b). To ascertain whether DivIVA forms the same oligomer in vivo, we performed Western blot analyses of B. subtilis cell lysates fractionated by blue native gel electrophoresis. It is evident that DivIVA from wild-type B. subtilis cell lysates forms the same oligomer as the purified DivIVA9 protein from E. coli (Fig. 1b; lanes 1 and 2). It is important to emphasize that with this technique we are examining the soluble DivIVA fraction. Western blots of SDS-PAGE gels revealed that up to $40 \%$ of DivIVA was associated with the membrane fraction (not shown). It is possible that membrane-associated DivIVA is assembled into the ring-like structure that has been observed 

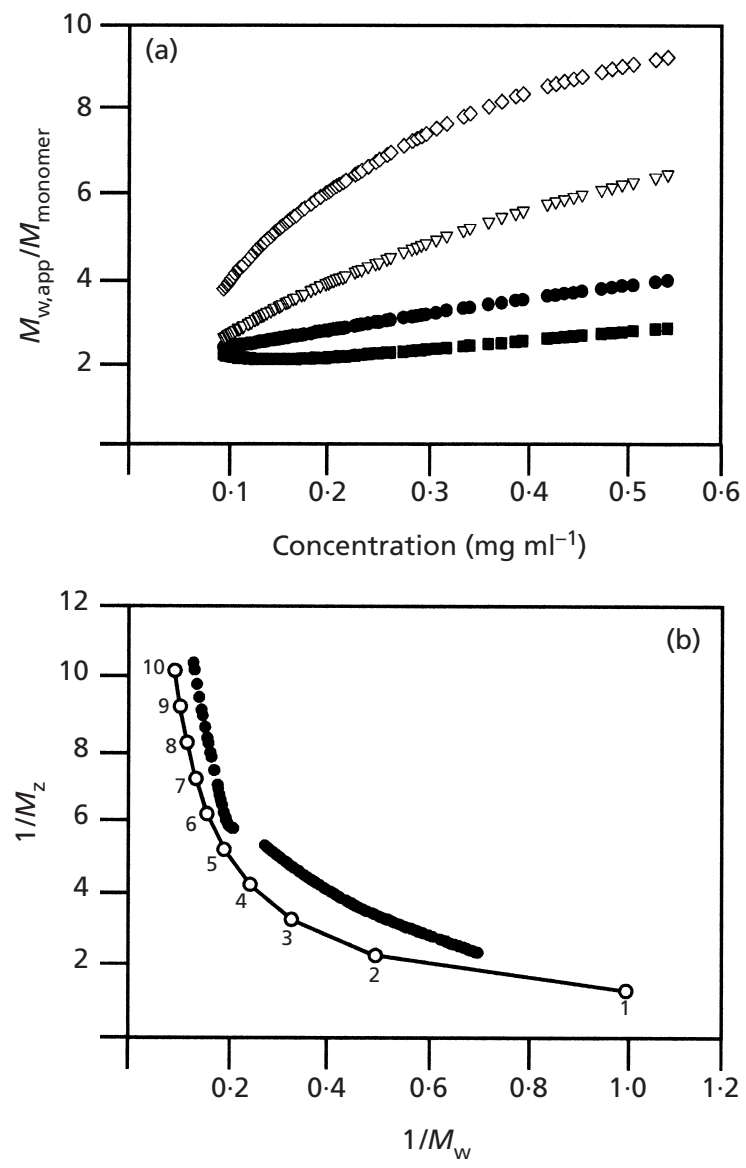

Fig. 2. (a) Molecular mass averages of DivIVA9 derived from analytical ultracentrifugation at a rotor speed (Beckman AnTi rotor) of 15000 r.p.m. The molecular mass averages generated are: number average, $M_{\mathrm{n}}$ (filled circles); $M_{\mathrm{y}, 1}$, the smallest observable species (filled squares); molecular mass average, $M_{\mathrm{w}}$ (open triangles) and $z$-average molecular mass, $M_{z}$ (open diamonds). The smallest observable species is a dimer, whereas the largest is at least a 10 mer. (b) Two species plot of $1 / M_{w}$ vs $1 / M_{z}$ of two loading concentrations of DivIVA9 at 15000 r.p.m. (closed circles). The open circles represent the calculated molecular masses of each of the oligomeric species as a comparison. Here it can be seen that the molecular mass averages extend from values associated with a dimer to that associated with at least a 10 mer.

previously at mid-cell and polar septal sites (Edwards \& Errington, 1997). It is not known whether DivIVA 10-12 mers observed here are intermediates for the assembly of these rings.

Western blot analysis of $B$. subtilis cell lysates revealed the presence of the same 10-12 mer in the divIVA1 mutant strain (Fig. 1b; lane 3). This allele contains a $G$ to A transition, resulting in an alanine to threonine substitution at amino acid residue 78 . It is predicted that this amino acid is located in the hydrophobic core of the proposed coiled-coil structure. This suggests that the loss of DivIVA function in this mutant strain is not due to altered oligomerization and that oligomerization per $s e$ is not sufficient for correct DivIVA function. An alternative interpretation is that this mutation affects the interaction of DivIVA with other components of the division machinery. The single DivIVA band corresponding to the 10-12 mer with no trace of smaller or higher order oligomeric forms is in contrast to the analytical ultracentrifugation observations, which suggest oligomers ranging from dimers to 10-12 mers. We assume that in native blue electrophoresis experiments the $10-12$ mer of DivIVA is stabilized by the glycerol present in the sample buffer in these experiments.

In contrast to the above, the protein DivIVA2 behaves differently, with 5-6 mer complexes prominent in addition to the 10-12 mers (Fig. $1 \mathrm{~b}$; lane 5). The $B$. subtilis IB704 strain harbouring the divIVA2 mutation grows so poorly that we were unable to load enough cell lysate to clearly detect the DivIVA2 protein. Fig. 1(b) shows recombinant DivIVA2 in an E. coli cell lysate (lane 5). The divIVA2 mutation causes a Leu to Pro substitution at amino acid residue 120 , which is also predicted to be located in the hydrophobic core, but at the end of the proposed coiled-coil structure. This mutation is probably not compatible with the proposed coiled-coil structure in this region (Edwards et al., 2000).

\section{Biological effect of divIVA mutations}

The divIVA1 mutation causes a misplacement of the septum during vegetative growth, resulting in the formation of mini-cells and filaments (Cha \& Stewart, 1997; Edwards \& Errington, 1997). To check the phenotype of the divIVA9 and divIVA2 mutants, we transformed derivatives of plasmid pUK19 containing the cloned mutant genes into the wild-type $B$. subtilis strain PY79 selecting for kanamycin resistance. Correct recombination by a single crossover event to replace the wild-type copy of $\operatorname{divIVA}$ with the two mutant genes was checked by Southern blot hybridization analysis (not shown). Light microscopy revealed that the divIVA9 mutation has no significant effect on cell length or morphology, and no mini-cells were observed (Fig. $3 \mathrm{a}, \mathrm{c})$. In contrast, the $\operatorname{divIVA2}$ mutant has a similar phenotype to divIVA1 mutant cells, characterized by longer cells and easily detectable mini-cells (Fig. 3b, d). The formation of septa in the wild-type and mutant $\operatorname{divIVA}$ strains was observed by fluorescence microscopy using the vital stain FM 4-64 (Fig. 3a*-d*). This stain specifically labels the lipid bilayer of the plasma membrane and is useful for the detection of septa (Pogliano $e t$ al., 1999). Normal septa are formed in wild-type and divIVA9 mutant strains, in contrast to the divIVA1 and divIVA2 mutant strains in which many partially formed septa are visible (Fig. 3a"-d").

DivIVA is a key protein in septum positioning during binary fission in B. subtilis and the elucidation of its function is crucial for our understanding of bacterial cell division. In addition to its role in mid-cell division, DivIVA may also be involved in the regulation of polar division, a process that occurs at the onset of spore formation. Multimerization of DivIVA appears to be an important element in its biological function. The 

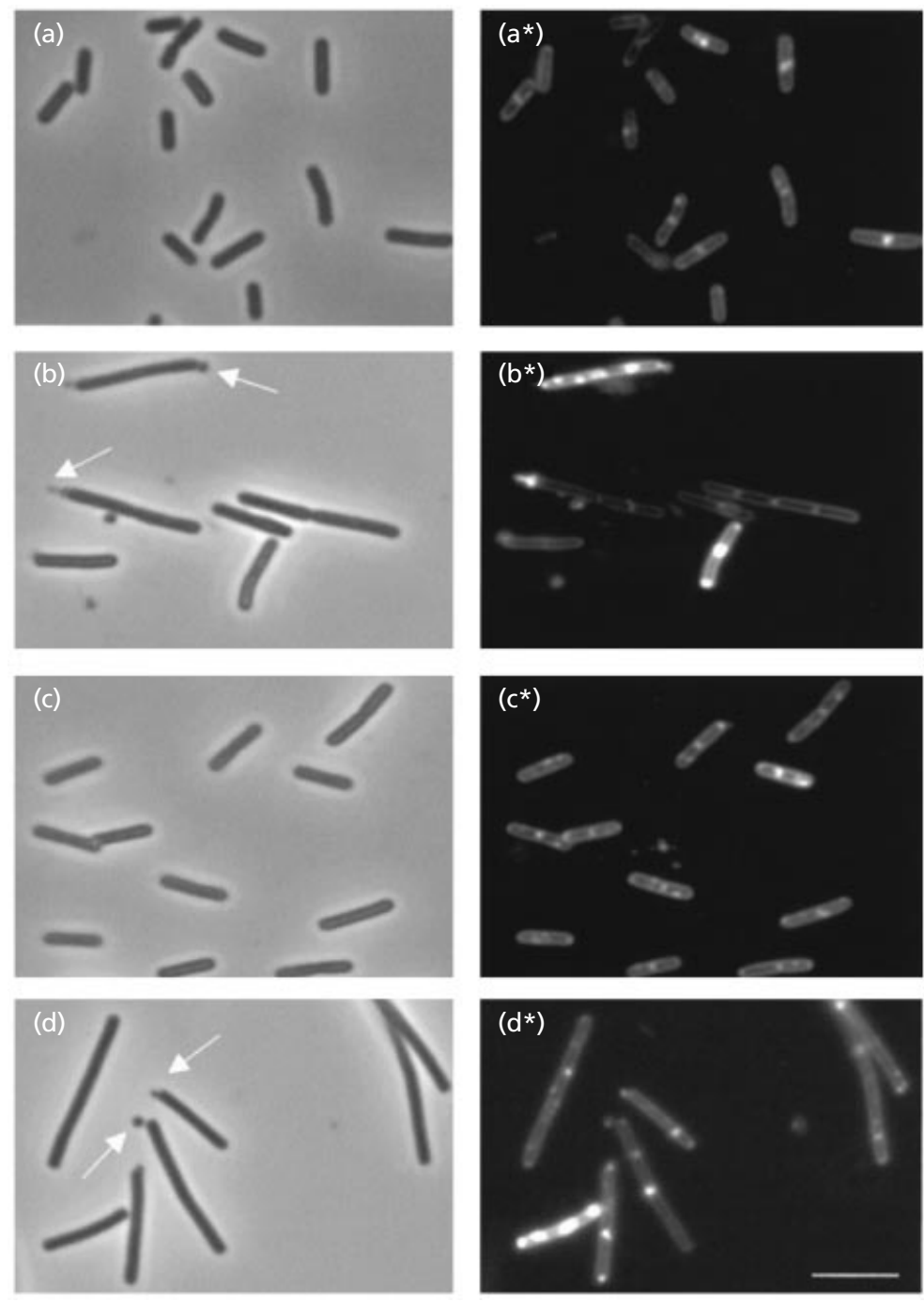

Fig. 3. Light and fluorescence micrographs of $B$. subtilis late-vegetative growth cultures of the following strains: $a$ and $a^{*}$, wild-type PY79; $b$ and $b *, K S S 1168$ (divIVA1); $c$ and $c^{*}$, IB703 (divIVA9); d and d*, IB704 (divIVA2). Panels $a, b, c$ and $d$ are light micrographs, where the formation of mini-cells is marked by arrows. Panels marked with an asterisk are fluorescence micrograph counterparts of panels $a, b, c$ and $d$, showing cell membranes by detection of the fluorescent stain FM 4-64. The scale bar $(4 \mu \mathrm{m})$ is at the bottomright of the panel. smallest observable species corresponds to a dimer, and the largest to either a 10,11 or 12 mer. Macromolecules that exhibit a mixture of five- and twofold symmetry occur frequently in biology, a well-known example being viruses. Similarly, RecA displays six- and twofold symmetry (Brenner et al., 1990), and the functional unit of the RNA-binding protein from B. subtilis, TRAP, with which our laboratory is familiar is an 11 mer (Antson et al., 1999). Clearly, the oligomerization of DivIVA raises new questions requiring additional experimentation.

\section{ACKNOWLEDGEMENTS}

The authors thank G. C. Stewart for supplying B. subtilis strain KSS1168. We would also like to thank Mrs Helena Kolesárová for technical assistance. This work was supported by grant 5025 from the Slovak Academy of Sciences and Wellcome Trust Grants 047031/Z96/Z and 056247/Z/98/Z. R.J.L. is a Wellcome Trust Research Career Development Fellow. J.A.B. is funded by the BBSRC York Structural Biology Centre. D.J.S. is supported by the Wellcome Trust and the York Structural Biology Centre.

\section{REFERENCES}

Antson, A. A., Dodson, E. J., Dodson, G., Greaves, R. B., Chen, X. P. \& Gollnick, P. (1999). Structure of the trp RNA-binding attenuation protein, TRAP, bound to RNA. Nature 401, 235-242.

Ausubel, F. M., Brent, R., Kingston, R. E, Moore, D. O., Seidmann, J. S., Smith, J. \& Struhl, K. (1987). Current Protocols in Molecular Biology. New York: Wiley.

Backman, K., Ptashne, M. \& Gilbert, A. W. (1976). Construction of plasmids carrying the $c I$ gene of bacteriophage lambda. Proc Natl Acad Sci U S A 73, 4174-4178.

Barák, I., Behari, J., Olmedo, G., Guzmán, P., Brown, D. P., Castro, E., Walker, D., Westpheling, J. \& Youngman, P. (1996). Structure and function of the Bacillus SpoIIE protein and its localization to sites of sporulation septum assembly. Mol Microbiol 19, 10471060.

Barák, I., Prepiak, P. \& Schmeisser, F. (1998). MinCD proteins control the septation process during sporulation of Bacillus subtilis. J Bacteriol 180, 5327-5333.

Brenner, S. L., Zlotnick, A. \& Stafford, W. F., III (1990). RecA protein self-assembly. II. Analytical equilibrium ultracentrifugation studies of the entropy-driven self-association of RecA. $J$ Mol Biol 216, 949-964. 
Cha, J.-H. \& Stewart, G. C. (1997). The divIVA minicell locus of Bacillus subtilis. J Bacteriol 179, 1671-1683.

Edwards, D. H. \& Errington, J. (1997). The Bacillus subtilis DivIVA protein targets to the division septum and controls the site specificity of cell division. Mol Microbiol 24, 905-915.

Edwards, D. H., Thomaides, H. B. \& Errington, J. (2000). Promiscuous targeting of Bacillus subtilis cell division protein DivIVA to division sites in Escherichia coli and fission yeast. EMBO J 19, 2719-2727.

Fu, X., Shih, Y.-L., Zhang, Y. \& Rothfield, L. I. (2001). The MinE ring required for proper placement of the division site is a mobile structure that changes its cellular location during the Escherichia coli division cycle. Proc Natl Acad Sci U S A 98, 980-985.

Harding, S. E. (1994). Determination of absolute molecular weight by sedimentation equilibrium analytical ultracentrifugation. In Methods in Molecular Biology, vol. 22, pp. 74-84. Edited by C. Jones, B. Mulloy \& A. H. Thomas. Totowa, NJ: Humana Press.

Harwood, C. R. \& Cutting, S. M. (1988). Molecular Biological Methods for Bacillus. New York: Wiley.

Laue, T. M. \& Stafford, W. F., III (1999). Modern applications of analytical ultracentrifugation. Annu Rev Biophys Biomol Struct 28, 75-100.

Levin, P. A. \& Losick, R. (1996). Transcription factor Spo0A switches the localization of the cell division protein FtsZ from a medial to a bipolar pattern in Bacillus subtilis. Genes Dev 10, 478-488.

Lupas, A. (1996). Coiled coils: new structures and new functions. Trends Biochem Sci 21, 375-382.

Marston, A. L. \& Errington, J. (1999). Selection of the midcell division site in Bacillus subtilis through MinD-dependent polar localization and activation of MinC. Mol Microbiol 33, 84-96.

Marston, A. L., Thomaides, H. B., Edwards, D. H., Sharpe, M. E. \& Errington, J. (1998). Polar localization of the MinD protein of Bacillus subtilis and its role in selection of the mid-cell division site. Genes Dev 12, 3419-3430.
Pogliano, J., Osborne, N., Sharp, M. D., Abanes-De Mello, A., Perez, A., Sun, Y.-L. \& Pogliano, K. (1999). A vital stain for studying membrane dynamics in bacteria: a novel mechanism controlling septation during Bacillus subtilis sporulation. Mol Microbiol 31, 1149-1159.

Raskin, D. M. \& de Boer, P. A. J. (1997). The MinE ring: an FtsZindependent cell structure required for selection of the correct division site in E. coli. Cell 91, 685-694.

Raskin, D. M. \& de Boer, P. A. J. (1999). Rapid pole-to-pole oscillation of a protein is required for directing division to the middle of Escherichia coli. Proc Natl Acad Sci USA 96, 4971-4976.

Roarke, D. E. \& Yphantis, D. A. (1969). Studies of self-associating systems by equilibrium ultracentrifugation. Ann N Y Acad Sci 164, 245-278.

Rothfield, L. I. \& Zhao, C.-R. (1996). How do bacteria decide where to divide? Cell 84, 183-186.

Schägger, H., Cramer, W. A. \& von Jagow, G. (1994). Analysis of molecular masses and oligomeric states of protein complexes by blue native electrophoresis and isolation of membrane protein complexes by two-dimensional native electrophoresis. Anal Biochem 217, 220-230.

Youngman, P., Perkins, J. B. \& Losick, R. (1984). Construction of a cloning site near one end of Tn917 into which foreign DNA may be inserted without affecting transposition in Bacillus subtilis or expression of the transposon-borne erm gene. Plasmid 12, 1-9.

Zhang, Y., Rowland, S., King, G., Braswell, E. \& Rothfield, L. (1998). The relationship between hetero-oligomer formation and function of the topological specificity domain of the Escherichia coli MinE protein. Mol Microbiol 30, 265-273.

Received 25 June 2001; revised 13 September 2001; accepted 1 November 2001. 